\title{
Facilities Improvement Through Public-Private Partnership for Enhancing Foundation Skills Among Technical Vocational Education Students in Nigeria
}

\author{
Olabiyi Oladiran Stephen ${ }^{1}$, Benjamin O. Okafor ${ }^{2} \&$ Bamidele O. Ebenezer ${ }^{3}$ \\ ${ }^{1}$ Department of Science and Technology Education, University of Lagos, Akoka, Nigeria \\ ${ }^{2}$ Department of Quantity Surveying, Federal Polytechnic, Ilaro, Ogun State, Nigeria \\ ${ }^{3}$ Department of Building Technology, Federal Polytechnic, Ilaro, Ogun State, Nigeria \\ Correspondence: Olabiyi Oladiran Stephen, Department of Science and Technology Education, University of \\ Lagos, Akoka, Nigeria. E-mail: solabiyi@unilag.edu.ng; olabiyidiran@gmail.com
}

Received: May 29, 2013 Accepted: October 11, 2013 Online Published: March 6, 2014

doi:10.5539/enrr.v4n2p11 URL: http://dx.doi.org/10.5539/enrr.v4n2p11

\begin{abstract}
Technical vocational education and training (TVET), gives students the opportunities to gain the skills they need to enter the workforce, or to upgrade their skills for an existing job or new emerging occupation. Therefore, this study was designed to determine facilities improvement through public-private partnership (PPP) towards enhancing foundations skills among TVE Students in Nigeria. Four research questions and five null hypotheses, tested at .5\% level of significance, guided the study. The population for the study consisted of 205 respondents made up of two groups namely: 125 TVE teachers in post secondary institutions and 80 employers of TVE graduates. Mean and standard deviation were used to answer the research questions, while independent sample t-test was employed to test the null hypotheses. The findings of the study among others revealed the foundation skills required by TVE students include: career development, entrepreneurship, leadership and teamwork, information technology and safety, health and environment, while the facilities required in developing foundation skills among others are; transportation, hospital, library, telecommunication, traffic control and electric power system. It was recommended that contents of foundation skills identified should be validated by group of employers, TVE teachers, and other stakeholders, and effective instructional framework should be established for implementation during the development of foundation skills in students/workforce.
\end{abstract}

Keywords: foundations skills, technical vocational education, public-private partnership, infrastructure improvement

\section{Introduction}

The implication of the recent privatisation and investment in the various sectors of the Nigeria's economy is that there will be a rising demand for skilled personnel in the industrial development of Nigeria. To achieve Nigeria's vision 20: 20-20, there is a need for the acquisition of new skills and adaptation of these skills to industrial structure. The increasing demand for skilled manpower in Nigeria's emerging market economy highlights the developmental roles of technical vocational education (TVE) programme. Okoro (1999) defined vocational education as any form of education by which an individual's gain experiences and learns to carry out any successfully and useful occupation. These experiences may be organised and institutionalised or unorganised and haphazard. Simply put, vocational education is a series of controlled and organised arrangement to prepare a person for socially useful employment in a recognised occupation. A more encompassing definition of vocational education is given by Thomson (2002) as an instructional programme which includes general studies, practical training for the development of skills required by the chosen occupation and related theory, in which the proportion of these components vary considerably depending on the programme (vocational agric, vocational business, vocational home economics and vocational technical), but emphasis is usually on practical training. By implication, vocational education develops in individuals psychomotor, cognitive and affective skills, so that they can take their rightful place in the society.

Vocational education is more all-embracing than technical education. The latter is seen as a post-secondary vocational training programme whose primary purpose is to produce self-reliant technicians who are technical 
driven with affective skill in different occupations. Technical vocational education, according to the Nigeria National Policy on Education (2004), is a comprehensive term referring those aspects of the educational process involving, in addition to general education, the study of technologies and related sciences and the acquisition of practical skills, attitudes, understanding and knowledge relating to occupations in various sectors of economic and social life. Technical vocational education (TVE) therefore, is the process of teaching individuals the systematic skills, knowledge and attitude that are involved in the production of specific products or services. It incorporates the total learning experiences offered in educational ideas and abilities to make matured judgments and be in a position to create goods and services in the area of business education, industrial technical education, computer education, home economics education, agricultural education and fine and applied arts education. In a nutshell, TVE prepares human resources for the ever changing world of work. For effective participation in the world of work the 'study of technologies and related sciences' is of paramount significance and this can be enhanced through public-private partnership arrangement.

Technical vocational education (TVE) in the views of Okorie (2001) has a good potential of creating jobs for the unemployed graduates, and reducing poverty level of the people since those who have undergone training in this area can establish their own businesses thereby getting income to take care of their families, and making people stand on their own economically without depending on other people (self-reliance). Productive, competent and flexible personnel are a prerequisite for further economic development. Technical vocational education through public-private partnership (PPP) will increase expertise and capacity of technical institutions to provide education and foundation skills to the populace.

The perception of Public-Private Partnership (PPP) in TVE recognises the existence of alternative options for providing educational facility and services besides public finance and public delivery. Public-Private partnership according to Ahmed (2010) refers to a contractual agreement between a government agency or authority and a private sector entity that allows for greater private participation in the delivery of public infrastructure project. Facilities developments are the structures and facilities e.g. radio, sewage disposal, communication, road, power, hostel and building or workshop, telecommunication, library, solar energy, traffic control, transportation, electric power system needed for the effective operation of technical vocational education programme (Ahmed, 2010; Okoro, 1993). Pearson (2000) describes facilities as rooms, equipment or services that are provided for particular purpose. The facilities used for technical education programme include among the following infrastructure, equipment supplied, library facilities, communication and recreational facilities and environment.

The fundamental objective of a PPP is to encourage the private sector to use its facility to raise capital and the capability to build projects on time and to budget for the welfare of the technical vocational institutions, without having to compromise its profit motive. At the same time, technical institutions would retain its responsibility to provide goods and services to the public at affordable rates (Aimola, 2010). This arrangement according to Aimola calls for a judicious approach to decision making and underscores the need for a framework that enables the private sector partner to make reasonable returns on investments without diluting the standards and quality of services provided under public-private partnership arrangements, also any nation that is aspiring for self-sufficiency, political and economic emancipation cannot keep away from effective technical education program which can only be achieved through appropriate management of facilities.

The utmost concerns of employers today are finding good workers and training them. The difference between the skills needed on the job and those possessed by applicants, sometimes called the skills-gap, is of real concern to human resource managers and business owners looking to employ competent employees. Employers need reliable, responsible employees who can solve problems and who have the social skills and attitudes to work together with other workers. Creativity, once a trait avoided by employers who used a cookie cutter system, is now prized among employers who are trying to create the empowered, high performance workforce needed for competitiveness in today's marketplace (Jacquelyn, 2000). Employees with these skills are in high demand and are considered valuable human capital assets to companies. The foundation skills for career in Technical vocational education (TVE) are important competencies that students pursuing any career pathway should exhibit to be successful. The foundation skills should be developed from an analysis of all pathways in the occupational areas. Technical vocational education need to provide learners with a broad foundation for managing lifelong learning and career transitions in a rapidly changing economy and link to the academic performance standards.

\section{Statement of the Problem}

Technical vocational education plays a significant role in development of work force for the socio-economic growth and development of a country. Research findings (Federal Ministry of Education (FME), 2003; UNESCO, 2005) have shown that countries that are experiencing breakthrough in the technological world today are those that 
have placed more emphasis and invested substantially in TVE. Employers need reliable, responsible workers who can solve problems and who have the social skills and attitudes to work together with other workers (Jacquelyn, 2000), yet technical vocational institutions are unable to respond to the changing labour market requirements. The mismatch is traceable to poor infrastructural facilities, Gaps in facility quality; limited linkage with employer needs resulting in low or poor workforce skills. Wignall (2010) stated that we are living in a time of skill shortages arising from demographic and technological change and the proportion of jobs requiring vocational education and training qualifications is expected to significantly increase in the future, yet the capacity of many individuals to improve their skill is constrained by poor language, literacy and numeracy. Based on the fore-going, this study investigated the facilities improvement through public-private partnership towards enhancing foundation skills among TVE Students in Nigeria.

\subsection{Purpose of the Study}

Based on the fore-going the study investigates the facilities improvement through public-private partnership towards enhancing foundation skills among TVE Students in Nigeria. Specifically, the study determines the facilities and service that are required for enhancing foundations skills through; roles of public partnership in enhancing foundations skills of technical vocational students and ways of removing barriers to development foundation skills.

\subsection{Research Questions}

1) What are the foundation skills that are required by TVE students to fit and remain in the work environment?

2) What are the facilities and service that are required for enhancing foundation skills by technical vocational students?

3) What are the employer's roles in enhancing foundation skills of technical vocational students?

4) What are the ways of developing foundation skills among technical vocational students?

\subsection{Research Hypotheses}

$\mathrm{Ho}_{1}$ : There will be no significant difference in the mean responses of TVE teachers in post-secondary technical institutions and employers regarding foundation skills that are required for enhancing foundation skills of TVE students to fit and remain in the work environment.

$\mathrm{Ho}_{2}$ : There will be no significant difference in the mean responses of TVE teachers in post-secondary technical institutions and employers regarding facilities and service that are required for enhancing foundation skills of TVE students.

$\mathrm{Ho}_{3}$ : There will be no significant difference in the mean responses of technical vocational teachers in post-secondary technical vocational institutions and employers regarding employer's roles in enhancing foundation skills of technical vocational students.

$\mathrm{Ho}_{4}$ : There will be no significant difference in the mean responses of male and female technical vocational teachers regarding employer's roles in enhancing foundation skills of technical vocational students.

$\mathrm{Ho}_{5}$ : There will be no significant difference in the mean responses of technical vocational teachers in post-secondary technical vocational institutions and employers regarding ways of developing foundation skills among technical vocational students.

\subsection{Review of Related Literature}

Foundation skills development involves skills acquisition and the critical application of these skills in multiple environments for multiple purpose, and these skills include: entrepreneurship safety, health and environment, leadership and teamwork, information technology applications, problem solving and critical thinking, communications and career development. Foundation skills according to Roberts and Wignall (2010) are fundamental to participation in the workplace, the community and training. The importance of strong foundation skills in a modern, knowledge-based society is well recognized. These skills strengthen workforce participation, productivity and social inclusion. People with higher foundation skills are more likely to be employed, participate in their community, experience better health and engage in further training.

Jacquelyn (2000); Hartley and Horne (2006) mentioned that foundation skills are critically important to people gaining employment and remaining employed. The link between numeracy, literacy and problem solving skills and the central use of technology in contemporary communication means that foundation skills are increasingly important for effective participation in modern workplaces and contemporary life. Workforce development strategies include activities which increase the capacity of individuals to participate effectively in the workforce 
through their working life and which increase the capacity of enterprises to adopt high performance work practices (Coulombe, Tremblay, \& Marchland, 2004) For many individuals, improving their foundation skills is a challenging, lengthy and involved process, as it requires the use and development of complex cognitive and communication skills. Skilled education and training workforce are critical to ensuring that learners receive education and training that meet their foundation skills needs, in high quality, engaging and providing an effective pathway into work or further education.

Governments have long recognised the importance of industry, employers and unions in improving the skills, including foundation skills, of those in the labour force. Strong and lasting partnerships will be integral to promoting and building a culture of integrating foundation skills into training opportunities provided in the workplace (Jacquelyn, 2000). Over the next decade, Nigerian governments should form partnerships with industry, employers and unions to maximize the opportunities for workplace foundation skills development. A range of funded opportunities for workplace skill building programmes will be required not only to assist enterprises to develop an understanding of how foundation skills issues are directly linked with the success of a business and the development of the community as a whole, but also to promote innovative and customised training models and explore opportunities for enterprises to cluster together to access tailored, integrated training relevant to their industry and their work site requirements. Public-private partnerships (PPPs) can deliver substantial innovation to education infrastructure and service delivery. The concept of PPPs in vocational education recognizes the existence of alternative options for providing educational facility and services besides public finance and public delivery.

Nigeria should explore ways of using PPPs to alleviate infrastructure shortages in its education system and continue to invest in necessary facilities, especially in technical vocational education (Ahmed, 2010). Thus, facilities in TVE institutions should be consistently revisited and upgraded in line with the current realities (Enebe, 2000). Increasing the private sector's role in technical vocational education in Nigeria through public-private partnership according to Ahmed (2010) have several benefits over the traditional public delivery of education, including greater efficiency. Increased private involvement in education through Private partnership possibly will increase expertise and responsible workers who can solve problems and who have the social skills and attitudes to work together with other workers.

\section{Methodology}

The study employed a descriptive survey research design. Structured questionnaires were used as instrument to collect data from the respondents. The population of interest for the study consisted of 205 respondents' made up of two groups namely: 125 technical vocational teachers in post TVE institutions and 80 employers of TVE graduates. SPSS computer programme was used as a template for data analysis. Mean and standard deviation were employed to answer the research questions and independent samples t-test was used to test the null hypotheses. Any item with the mean value of 3.50 and above was considered as acceptable and the hypothesis of no significance difference was accepted at probability of $.5 \%$ level of significance. The questionnaire was structured in line with research questions in Likert type containing 40 items for the purpose of collecting data for the study. The instrument was evaluated for content and face validity by three experts. The experts included two lecturers from Science and Technology Education Department, University of Lagos and a training officer from Industrial Training Funds.

\section{Results}

\subsection{Research Question and Hypothesis 1}

What are the foundations skills that are required by TVE students to fit and remain in the work environment?

$\mathrm{Ho}_{1}$ : There will be no significant difference in the mean responses of technical vocational teachers in post-secondary technical institutions and employers regarding the foundation skills that are required by TVE students to fit and remain in the work environment.

Table 1. Mean, SD and t-test Analysis of the responses of TVE teachers and employers regarding the foundation skills required by TVE students to fit and remain in the work environment $\mathrm{N}=205$

\begin{tabular}{cccccc}
\hline Group & Mean & SD & Df & $t$ & $\mathrm{P}$ \\
\hline TVE teachers & 70.23 & 13.62 & & & \\
Employers & 67.34 & 13.33 & 217 & 1.504 & .134 \\
\hline
\end{tabular}


Table 1 above, revealed that technical vocational teachers recorded a higher mean score $(\mathrm{M}=70.23$ and $\mathrm{SD}=$ 13.62) than employers counterparts $(\mathrm{M}=67.34$ and $\mathrm{SD}=13.33)$ on the foundation skills that are required by TVE students to fit and remain in the work environment. This difference in mean score was however not statistically significant $\left(\mathrm{t}_{217}=1.50, \mathrm{p}=.134\right)$. The null hypothesis was therefore not rejected and we concluded that there was no statistically significant mean difference between the mean responses of TVE teachers in post-secondary technical institutions and employers regarding the foundation skills that are required by TVE students to fit and remain in the work environment.

\subsection{Research and Hypothesis 2}

What are the facilities and service that are required for enhancing foundation skills of technical vocational students?

$\mathrm{Ho}_{2}$ : There will be no significant difference in the mean responses of TVE teachers in post-secondary technical institutions and employers regarding facilities and service that are required for enhancing foundation skills of technical TVE students.

Table 2. Mean, SD and t-test Analysis of the responses of TVE teachers and employers regarding the facilities and services that are required for enhancing foundation skills by TVE students $\mathrm{N}=205$

\begin{tabular}{cccccc}
\hline Group & Mean & SD & Df & t & P \\
\hline TVE teachers & 73.23 & 14.60 & & & \\
Employers & 70.34 & 12.30 & 217 & 1.504 & .134 \\
\hline
\end{tabular}

Table 2 above, revealed that TVE teachers recorded a higher mean score $(\mathrm{M}=73.23$ and SD $=14.60)$ than employers counterparts $(\mathrm{M}=70.34$ and $\mathrm{SD}=12.30)$ on the facilities and service that are required for enhancing foundation skills by TVE students to fit and remain in the work environment. This difference in mean score was however not statistically significant $\left(\mathrm{t}_{217}=1.50, \mathrm{p}=.134\right)$. The null hypothesis was therefore not rejected and we concluded that there was no statistically significant mean difference between the mean responses of TVE teachers in post-secondary technical institutions and employers regarding the facilities and service that are required for enhancing foundation skills by TVE students to fit and remain in the work environment.

\subsection{Research Question and Hypothesis 3}

What are the employer's roles in enhancing foundation skills of technical vocational students?

$\mathrm{Ho}_{3}$ : There will be no significant difference in the mean responses of TVE teachers in post-secondary TVE institutions and employers regarding the employer's roles in enhancing foundation skills of TVE students.

Table 3. Mean, SD and t-test Analysis of the responses of TVE teachers and employers regarding the employer's roles in enhancing foundation skills of technical vocational students $\mathrm{N}=205$

\begin{tabular}{cccccc}
\hline Group & Mean & SD & Df & t & P \\
\hline TVE teachers & 66.41 & 6.82 & & & \\
Employers & 68.53 & 4.10 & 217 & -2.48 & .014 \\
\hline
\end{tabular}

Table 3 shows the comparison of TVE teachers and employers of labour towards the employer's roles in enhancing foundation skills of technical vocational students. The mean score of employers $(\mathrm{M}=68.53 ; \mathrm{SD}=4.10)$ is higher than mean score of TVE teachers $(\mathrm{M}=66.41 ; \mathrm{SD}=6.82)$. However, the difference in mean score was statistically significant $\left(\mathrm{t}_{217}=-2.48, \mathrm{p}=.014\right)$. The null hypothesis was therefore rejected and we concluded that there was a statistically significant mean difference between the mean responses of TVE teachers in post-secondary technical institutions and employers regarding the employer's roles in enhancing foundation skills of technical vocational students.

\subsection{Research Question and Hypothesis 4}

What are the employer's roles in enhancing foundation skills of technical vocational students?

$\mathrm{Ho}_{4}$ : There will be no significant difference in the mean responses of male and female technical vocational teachers 
and employers regarding the employer's roles in enhancing foundation skills of technical vocational students.

Table 4. Mean, SD and t-test Analysis of the responses of male and female TVE teachers and employers regarding the employer's roles in enhancing foundation skills of TVE students $\mathrm{N}=205$

\begin{tabular}{cccccc}
\hline Group & Mean & SD & Df & $t$ & $P$ \\
\hline Female & 61.77 & 6.75 & & & \\
Male & 64.01 & 4.76 & 217 & -2.57 & .004 \\
\hline
\end{tabular}

Table 4 above, shows the comparison of male and female TVE teachers on the employer's roles in enhancing foundation skills of technical vocational students. Male TVE teachers recorded a higher mean score $(\mathrm{M}=64.01$ and $\mathrm{SD}=4.76)$ than their female counterparts $(\mathrm{M}=61.77$ and $\mathrm{SD}=6.75)$. This difference in mean score was however statistically significant $\left(\mathrm{t}_{217}=-2.57, \mathrm{p}=.004\right)$. The null hypothesis was therefore rejected and we concluded that there was a statistically significant mean difference between the mean responses of female and male TVE teachers regarding the employer's roles in enhancing foundation skills of technical vocational students.

\subsection{Research Question and Hypothesis 5}

What are the ways of developing foundation skills among technical vocational students?

$\mathrm{Ho}_{5}$ : There will be no significant difference in the mean responses of technical vocational teachers in post-secondary TVE institutions and employers regarding the ways of developing foundation skills among technical vocational students.

Table 5. Mean, SD and t-test Analysis of the responses of technical vocational teachers and employers regarding the ways of developing foundation skills among technical vocational students $\mathrm{N}=205$

\begin{tabular}{cccccc}
\hline Group & Mean & SD & Df & $t$ & P \\
\hline TVE teachers & 87.00 & 7.71 & & & \\
Employers & 85.77 & 3.06 & 217 & 1.32 & .030 \\
\hline
\end{tabular}

Table 5 above, revealed that TVE teachers recorded a higher mean score $(\mathrm{M}=87.00$ and $\mathrm{SD}=7.71)$ than employers of labour counterparts with $(\mathrm{M}=85.77$ and $\mathrm{SD}=3.06)$ on the ways of developing foundation skills among technical vocational students. This difference in mean score was however not statistically significant $\left(\mathrm{t}_{217}=\right.$ $1.32, \mathrm{p}=.030$ ). The null hypothesis was therefore rejected and we concluded that there was no statistically significant mean difference between the mean responses of technical vocational teachers in post-secondary technical institutions and employers regarding ways of developing foundation skills among technical vocational students.

\section{Discussion}

Based on the results of the study, the findings of the study revealed no significant difference between technical vocational teachers in post-secondary technical institutions and employers of labour regarding the foundation skills that are required by TVE students to fit and remain in the work environment. This suggests that TVE teachers and employers have the same perception about foundation skills. The findings is consistent with the views of Jacquelyn (2000) who stated the following (safety, health and environment, leadership and teamwork, information technology applications, problem solving and critical thinking, communications, entrepreneurship, and career development) as the skills, attitudes and actions that enable workers to get along with their fellow workers and supervisors and to make sound, critical decisions are very important. Studies carried out by Roberts and Wignall (2010); Lee Donald and Richard (1999) also are in agreement with the finding who that emphasised that the increasing complexity of modern workplaces and contemporary life means that for many, making the most of this opportunity means taking steps to strengthen their foundation skills. School and employer should provide a unique opportunity for more people to engage in the workforce and ensure that the benefits of work and economic prosperity are shared by all.

Hypothesis two, which sought the opinion of TVE teachers in post-secondary technical vocational institutions and employers regarding the facilities and service required for enhancing foundation skills by technical vocational 
students. It was observed that there is significant mean difference between the mean responses of TVE teachers in post-secondary technical institutions and employers regarding the facilities and service that are required for enhancing foundation skills by technical vocational students. The findings are established by Olaitan et al. (1999) and Thompson (2002) who emphasised that the components of service and facilities required of TVE vary considerably depending on the types of TVE programme some of the facilities identified are sewage disposal, transport, road, radio, telegraph, hospital, traffic control, equipment and tools, fixed facilities, consumables among others.

Furthermore, hypothesis three, which stated that there is no significant mean difference between the responses of TVE teachers and employers regarding the employer's roles in enhancing foundations skills of technical vocational students. This study found no statistically significant differences between TVE teachers and employers regarding the employer's roles in enhancing foundations skills. The mean scores TVE teachers (64.01) and employers (61.77) were an indication that TVE teachers perceive the employer's roles in enhancing foundation skills of technical vocational students more important than employers. The obvious implication of this finding is that employers of labour have significant role to play in developing in young people foundation skills. This further confirms the findings of Needleman (1995); Roberts and Wignall (2010) that employers should provide the required hours for student to earn academic credit depending on the type of assignment. Hours required will either be 10, 15, or 20 per week. However, depending on the needs of the business, the student may work more hours than what is required for course credit authors added. Jacquelyn (2000); Coulombe, Tremblay, and Marchland (2004) suggested that employers need to provides training programmes, with varied experiences, which will contribute to the education of the student; provide supervision/workplace mentor for the training of the student; provide employment for the student during the agreed upon times; and adhered to all state and federal child labour laws; providing for the day-to-day safety of the student on the job; authors further emphasised that provision training to the technical vocational students which matches the learning experiences to individual student capabilities; offering a well-rounded variety of learning experience for the student; and provides wages to the TVE students comparable to those paid to similar entry-level workers in the company are part of employer's role.

However, hypothesis four which sought the comparison of male and female TVE teachers on employer's roles in enhancing foundations skills of technical vocational students shows that there is significant difference in the opinion of male and female TVE teachers. This confirm the findings of Olaitan et al. (1999); Okorie (2001) who observed that the occupational choice of individuals is differ based on the orientation (interest, aptitude, ability ) of the individual and they should have the opportunity to select an career in harmony with his orientation and the opportunities for employment in that occupation.

Also, hypothesis five, which stated that there is no significant mean difference between the responses of TVE teachers in post-secondary TVE institutions and employers regarding ways of developing foundation skills among TVE students, The study found no statistically significant differences between TVE teachers and employers. This finding is in agreement with Okorie (2000); Lee and Richard (1999) who emphasized those workforce development strategies include activities which increase the capacity of individuals to participate effectively in the workforce through their working life and which increase the capacity of enterprises to adopt high performance work practices. In the views of Hartley and Horne (2006) they stressed that among the techniques that can be employed is to ensure day-to-day safety of the TVE students on the job and the curriculum should be developed and implement based upon a pre-employment, employment and post-employment skills.

\section{Implication of Findings}

The present study has shown that public-private partnership (PPP) initiative has a role to play in developing foundation skills among TVE students through the provision of infrastructural facilities. The study sensitizes the school and industry on the different foundation skills that should be developed by workforce and facilities and services that are required to develop these skills in technical vocational students, as foundation skills strengthen workforce participation, productivity and social interaction. People with higher foundation skills are more likely to be employed, participate in their community, experience better health and engage in further training. Therefore, school should partner with public to ensure effective development of these skills. The study further sensitize the employers of labour their role to offer the student the opportunity to gain valuable skills in a work-place setting to enhance the student's academic and future career goals through work-based programme such as internship and cooperative education among others.

\section{Conclusion}

The study sought to determine the role of Public-Private Partnership in infrastructure improvement towards enhancing foundations skills among TVE Students in Nigeria. However, the findings of this study revealed that the 
foundation skills required by TVE students include: career development, entrepreneurship, leadership and teamwork, information technology and safety, health and environment, while the facilities required include; hospital, library, internet, fire extinguishers and transport

\section{Recommendations}

1. Foundation skills identified in the study should be validated by group of employers, secondary educators, postsecondary educators, labour associations, and other stakeholders.

2. Government should ensure that they provide high-quality, work-based experiences for technical vocational students.

3. Technical vocational institutions should ensure that they connect student learning more directly to the world of work through internship or on-the-job training.

4. Facilities required in TVE institutions for effective integration of foundation skills into the learning of technical vocational education programme should be provided through public-private initiative as government alone cannot effectively shoulder the responsibility.

\section{References}

Ahmed, M. (2010). Managing Infrastructural/facilities in TVE Institutions through Public-Private Partnership in Technical and Vocational Education in Nigeria. A paper Presented at a National Workshop on Managing TVE Institutions in Nigeria. University of Ibadan.

Aimola, A. O. (2010). Milestone, Problems and Challenges in the Management of TVE Institutions in Nigeria. A paper Presented at a National Workshop on Managing TVE Institutions in Nigeria. University of Ibadan

Boedker, C., Cogin, J., Langford, P., Meagher, K., Mouritsen, J., Runnalls, ... Vidgen, R. (2011). Leadership, Culture and Management Practices of High Performing Workplaces in Australia: Literature Review and Diagnostic Instruments. Funded by the Department of Education, Employment and Workplace Relations, published by the Society for Knowledge Economics, January, 2011.

Coulombe, S., Tremblay, J., \& Marchland, S. (2004). Literacy scores, human capital and growth across fourteen OECD countries. Statistics Canada, Ottawa.

Enebe, P. A. (2000). Vocational Technical Education Teachers in Nigeria: Issues and their Implications for Vocational Technical Education. In C. T. O. Akinmade, T. O. Ojetunde \& G. O. Akpan (Eds.).

Federal Ministry of Education. (2000). Technical and Vocational Education Development in Nigeria in the $21^{\text {st }}$ century with the blue-print for the decade 2001-2010. Abuja: Federal Ministry of Education.

Federal Republic of Nigeria (2004): National Policy on Education (4 ${ }^{\text {th }}$ Ed.). Lagos NERDC Press

Hartley, R., \& Horne, J. (2006). Social and economic benefits of improved adult literacy: Towards a better understanding. Adelaide: National Centre for Vocational Education Research.

Jacquelyn, P. R. (September 15, 2000). What Are Employability Skills? The workplace: Volume 1, Issue 3.

Lee, D., \& Richard. (1999). Preparing the Workforce of Tomorrow: A conceptual Framework for Career and Technical Education. Journal of Vocational education research. Retrieved March 10, 2006 from http:www.scholor.lib.vt.ed/ejournals/JUER/v27nl/rojewski:html

Needleman, E. C. (1995). Preparing Youth for Employable Futures. Washington, D. C.: National 4-H Council.

Okorie, J. U. (2000). Developing Nigeria Workforce. Calabar: Page Environs Publishers.

Okoro, O. M. (2003). Principles and Methods in Vocational and Technical Education. Nsukka.

Pearson Education Limited. (2000). Longman Dictionary of Contemporary English. The Complete Guide to Written and Spoken English. England: Pearson Education Limited.

Roberts, A., \& Wignall, L. (2010). Briefing on Foundation Skills for the National VET Equity Advisory Council.

UNESCO. (2008). Toward Information Literacy Indicators. Paris: UNESCO. Available: http://unesdoc.unesco.org/ 


\section{Copyrights}

Copyright for this article is retained by the author(s), with first publication rights granted to the journal.

This is an open-access article distributed under the terms and conditions of the Creative Commons Attribution license (http://creativecommons.org/licenses/by/3.0/). 